\title{
Prosedur Penghimpunan Dana Tabungan Shar-e Dan Penyajian Laporan Keuangan Pada Bank Muamalat Cabang Manado
}

\author{
Nur Fitry Latief \\ (Email : nur.fitry@gmail.com)
}

\begin{abstract}
This study is a continuation of the study authors in 2008 that have not been issued with a variable and the same research object and aimed to evaluate the extent to which procedures Savings Fund Raising Shar-E run in the operational activities of savings products Shar-E so that later on when the financial statements of banks Muamalat published in accordance with the rules laid down in Requirements financial accounting standards (SFAS) No. 59 of accounting Islamic banking is executed.

The method used by the writer is descriptive research method with the primary data source (directly observed activities of employees of the accounting) and some secondary data (in the form of financial statements) whose purpose is to describe the state of the operational procedures of Muamalat bank branches serving customers Manado in savings products Shar -E and customer data entry system to the software to generate financial data in accordance with IAS 59, resulting in the presentation of the financial statements at the end of the closing presentation of the financial report that can be justified and the information presented is clear and fair information. While the techniques used were observation and interviews.

The research result shows that the system of Accounting at Bank Muamalat branch Manado related savings fund raising procedures Shar-E has followed the procedures established and consistently until now. This suggests that the Bank Muamalat Manado Branch has implemented rules contained in IAS (SFAS) No. 59 on Accounting for Islamic Banking theoretically.
\end{abstract}

Keywords: Procedures, Savings Fund Raising Shar-E and Presentation of Financial Statements.

\section{Pendahuluan}

Kehidupan bisnis perbankan Syariah sangat ditentukan berjalan tidaknya produkproduk yang dijual kepada nasabah. Kesemuanya ini sangat dipengaruhi oleh situasi prosedur produk yang dikembangkan dan dijalankan. Di dalam prosedur operasional Bank Syariah dapat dibedakan menjadi dua kelompok umum yaitu : prosedur kelompok produk penghimpunan (pengarahan) dana dan prosedur kelompok produk penyaluran dana atau pembiayaan.

Sehubungan dengan prosedur penghimpunan dana tabungan dalam hal ini produk tabungan Shar-E, maka tujuan penulis mengadakan penelitian adalah untuk mengevaluasi sejauh mana prosedur itu dijalankan dalam kegiatan operasional tabungan Shar-E sehingga nantinya pada saat laporan keuangan bank muamalat diterbitkan sesuai dengan aturan yang ditetapkan dalam persyaratan standar akuntansi keuangan (PSAK) No. 59 tentang akuntansi perbankan syariah, dan laporan keuangan yang disajikan dapat memberikan informasi yang jelas bagi masyarakat penggunanya. 


\section{Tinjauan Pustaka}

Prosedur menurut kamus bahasa Indonesia adalah cara kerja sesuatu atau kegiatan yang langsung pada suatu objek yang dilaksanakan terus menerus secara berkesinambungan, sedangkan prosedur penghimpunan dana adalah petunjuk rinci tentang cara kerja mengenai pengumpulan dana tabungan yang harus diperoleh pada suatu saat selama periode berjalan.

Bank berdasarkan prinsip syariah atau bank syariah atau bank Islam berfungsi sebagai lembaga intermediasi (intermediary institution), yaitu mengerahkan dana dari masyarakat dan menyalurkan kembali dana-dana tersebut kepada masyarakat yang membutuhkan dalam membentuk fasilitas pembiayaan. Perbedaan bank syariah dan bank konvensional adalah terletak pada kegiatan usahanya yang tidak berasarkan bunga (interest free), tetapi berdasarkan prinsip syriah yaitu prinsip pembagian keuntungan dan kerugian (profit and loss sharing principle atau PLS Principle) atau bagi hasil.

Bank Syariah adalah suatu sistem perbankan yang dikembangkan berdasarkan syariah (hukum) Islam. Sedangkan yang dimaksud dengan prinsip syariah adalah aturan perjanjian (akad) berdasarkan hukum Islam antara bank dan pihak lain untuk menyimpan dana, pembiayaan, kegiatan usaha dan kegiatan lainnya yang dinyatakan sesuai syariah.

Akad adalah penyataan keterikatan antara bank syariah dan nasabah yang merupakan dasar untuk melakukan transaksi di bank syariah. Tanpa akad maka seluruh transaksi yang dilakukan tidak sah menurut syariah Islam. Oleh karena itu maka semua transaksi dalam perbankan syariah harus dimulai dengan akad antara bank syariah dengan nasabahnya.

Bank syariah pada dasarnya sama dengan bank komersial lainnya yang sudah ada selama ini, berlaku untuk semua lapisan kalangan masyarakat, hanya saja dalam kegiatan operasionalnya bank syariah itu berdasarkan pada prinsip syariah.

Kegiatan dan karakteristik bank syariah menurut Sholihin Hasan (seorang pejabat pada bank Islam di Jeddah) bahwa "kegiatan usaha perbankan Islam meliputi semua kegiatan konvensional kecuali pinjaman dengan bunga. Ia menerima simpanan dan memberikan pinjaman, tetapi tidak menerima dan membayar bunga, yang dikutip oleh Muh. Zuhri dalam bukunya yang berjudul Riba dalam Al Qur'an dan Masalah Perbankan yang dipublikasikan oleh Penerbit PT. Raja Grafindo Persada tahun 1996 halaman 159. Sama halnya dengan pendapat Mohammad Arif (dosen university of malaya) dalam Islamic Banking, Asian-pasific economic literature, vol 2, No. 2 (september 1988), halaman 52 mengatakan bahwa perbankan Islam dapat memberikan jasa-jasa lebih daripada yang dapat diberikan oleh bank konvensional. Menurut muhammad Arif. f, "It is clear.... that Islamic banking goes beyond the pure financing activities of conventional banks. Islamic banks engage in equity financing and trade financing”.

Adalah keliru apabila ada yang memiliki persepsi bahwa jasa-jasa perbankan berkaitan dengan ritual keagamaan dari agama Islam. Jasa-jasa perbankan Islam sama sekali tidak ada kaitannya dengan ritual keagamaan. Oleh karena itu, bank syariah boleh memberikan fasilitas pembiayaan atau jasa-jasa perbankan syariah yang lainnya kepada nasabah yang bukan beragama Islam (Nasabah Non-Muslim).

Karateristik Bank Syariah meliputi : 
1. Universal yaitu diperuntukkan bagi semua orang tanpa memandang perbedaan kemampuan ekonomi maupun perbedaan agama.

2. Adil yaitu memberikan sesuatu hanya kepada yang berhak serta memperlakukan sesuatu sesuai posisinya dan melarang adanya unsure maysir (unsur spekulasi atau untung-untungan), gharar (ketidakjelasan), haram dan riba.

3. Transparan yaitu dalam kegiatan operasional Bank Syariah sangat terbuka bagi seluruh lapisan masyarakat.

4. Seimbang yaitu mengembangkan sector keuangan melalui aktivitas perbankan Syariah yang mencakup pengembangan sector riil dan UKM.

5. Maslahat yaitu bermanfaat dan membawa kebaikan bagi seluruh aspek kehidupan.

6. Produk bervariasi mulai dari tabungan haji dan umrah, tabungan umum, giro, deposito, pembiayaan yang berbasis bagi hasil, jual beli dan sewa menyewa, sampai kepada produk jasa custodian, jasa transfer dan jasa pembayaran (debit card, syariah charge).

7. Fasilitas penerimaan dan penyaluran zakat, infaq, sedekah, wakaf dana kebajikan (qard), memiliki fasilitas ATM, mobile banking, internet banking dan inter-koneksi antar bank syariah.

Menurut PSAK No.59 (Akuntansi Perbankan Syariah) bahwa laporan keuangan Bank Syariah yang lengkap terdiri dari kompenen-kompenen sebagai berikut :

a. Neraca

b. Laporan Laba Rugi

c. Laporan Arus Kas

d. Laporan Perubahan Ekuitas

e. Laporan Perubahan Dana Investasi Terikat

f. Laporan Sumber dan Penggunaan Dana Zakat, Infaq, dan Sedekah

g. Laporan Sumber dan Penggunaan Dana Qardhul Hasan

h. Catatan Atas Laporan Keuangan

Laporan-laporan tersebut harus diterbitkan dalam bentuk laporan korporatif yang mencakup laporan keuangan dari periode sebelumnya yang bisa dibandingkan. Metode penyajian dan pengungkapan pada laporan keuangan yang diterbitkan harus memungkinkan para pemakai untuk dapat membedakan antara perubahan sebenarnya di dalam posisi keuangan bank, hasil-hasil operasinya, cash flow-nya, investasi terbatas yang dikelola oleh bank, sumber-sumber penggunaan dan zakat dan dana sumbangan, serta sumber-sumber dan penggunaan dana qard dan perubahan akuntansinya selama periode yang dicakup oleh laporan keuangan.

Penyajian laporan keuangan tidak terlepas dari proses kegiatan operasional Bank Muamalat yang dilakukan sehari-hari dimana untuk memberikan informasi yang jelas dan wajar kepada nasabah serta kahalayak umum yang membutuhkannya. Kegiatan tersebut mengharuskan Bank Muamalat mengikuti prosedur yang telah ditetapkan pihak manajemen dan panduan dari Departemen Keuangan serta perbankan Nasional juga Majelis Ulama Indonesia (MUI). Kesemuanya ini dihimpun dalam pernyataan Standar Akuntansi Keuangan (PSAK) No.59 tentang Akuntansi Perbankan Syariah yang menjadi dasar dari setiap pembuatan Laporan Keuangan untuk semua Bank Syariah yang ada di Indonesia. 


\section{Metode}

Metode penelitian yang digunakan oleh penulis adalah metode penelitian deskriptif dengan tujuan adalah untuk melukiskan keadaan prosedur operasional dari bank muamalat cabang manado dalam melayani nasabah produk tabungan Shar-E dan sistem pemasukan data nasabah ke software untuk menghasilkan data keuangan yang sesuai PSAK No.59, sehingga dalam penyajian laporan keuangan pada tutup buku akhir tahun merupakan penyajian lapoan keuangan yang dapat dipertanggung jawabkan serta informasi yang disajikan adalah informasi yang jelas dan wajar.

Dalam mengumpukan data, teknik yang digunakan oleh penulis adalah teknik Observasi dimana penulis mendatangi objek yang akan diteliti dalam hal ini bank muamalat cabang manado, mengamati serta mencatat juga ikut membantu dalam pekerjaan karyawan untuk memastikan berjalannya prosedur operasional produk tabungan Shar-E dalam penerapan pernyataan standar akuntansi keuangan (PSAK) No. 59 khusus penyajian laporan keuangan bank muamalat cabang manado. Teknik selanjutnya yang penulis gunakan adalah wawancara untuk mengumpulkan data yang diperlukan tentang prosedur produk penghimpunan dana tabungan Shar-E pada bagian costumer servis (cs), bagian teller dan bagian akuntansi pada bank muamalat cabang manado.

Dalam menganalisis data, penulis menggunakan tekhnik analisis deskriptif kualitatif. Dimana tekhnik ini mengulas tentang kelancaran jalannya prosedur pelayanan produk Shar-E sampai munculnya data keuangan yang merupakan patokan dalam membuat laporan keuangan setiap akhir tahun yang berjalan sehingga dapat memastikan bahwa bank muamalat telah menjalankan ketentuan dalam PSAK No. 59 tentang akuntansi perbankan syariah, serta laporan keuangan yang disajikan adalah laporan keuangan yang dapat dipertanggungjawabkan juga dapat menggambarkan keadaaan bank muamalat cabang manado.

\section{Analisis dan Evaluasi}

Shar-E adalah produk kartu bertabungan yang ditujukan bagi Pemegang Kartu yang ingin berinvestasi syariah dengan fleksibel dan akses yang luas. Shar atau shariah artinya hukum atau hukum Islam. E (ain) artinya mata, lensa yang menerima cahaya syariah untuk disebarkan ke seluruh dunia. Shar-E (bisa dibaca Syar-I) artinya sesuatu Syariah Islam bertransaksi atas dasar keikhlasan dan Syariah. (bisa dibaca Share) yang aritnya berbagi hasil. Share-E diharapkan dapat menjadi pintu hijrah bagi umat menuju perbankan Syariah, sehingga asset umat dapat disalurkan kembali untuk sebesarbesarnya produktifitas umat.

Kehidupan bisnis perbankan Syariah sangat ditentukan berjalantidaknya produk-produk yang dijual kepada nasabah. Kesemuanya ini sangat dipengaruhi oleh situasi prosedur produk yang dikembangkan dan dijalankan. Di dalam prosedur operasional produk Bank Muamalat dibedakan menjadi dua kelompok umum, yaitu :

1. Prosedur Produk Penghimpunan / Pengerahan Dana terdiri dari:

a. Produk Tabungan : Shar-E, Ummat dan Arafah

b. Produk Deposito : Mudharabah dan Fulinvest

c. Produk Giro : Wadiah

d. DPLK (Dana Pensiun Lembaga Keuangan) Muamalat 
2. Prosedur Produk Penanaman / Penyaluran Dana terdiri dari :

a. Konsep Jual Beli

a) Murabahah adalah jual beli barang sesuai harga asal yang ditambahkan dengan keuntungan yang disepakati. Harga jual tidak boleh berubah selama masa perjanjian.

b) Salam adalah pembelian barang yang diserahkan dikemudian hari dimana pembayaran dilakukan di muka, tunai.

c) Istishna' adalah jual beli barang dimana produsen ditugakan untuk membuat suatu barang pesanan dari pemesan.

b. Konsep Bagi Hasil

c. Konsep Sewa

3. Prosedur Menjadi Nasabah Share-E

Untuk menjadi nasabah Produk Tabungan Share-E terdiri dari dua cara yaitu:

3.1 Prosedur pertama Pembukaan Rekening melalui Kantor Cabang bank Muamalat Tbk Manado, sebagai berikut :

3.1.1 Calon Pemegang Kartu membeli paket perdana dengan harga sesuai ketentuan yang berlaku yaitu Rp. 125.000,00 (seratus dua puluh lima ribu) perpaket;

3.1.2 Persedian paket perdana Share-E disimpan dan deregister oleh Customer Service Cabang;

3.1.3 Paket perdana Share-E harus disimpan dalam khasanah utama;

3.1.4 Customer Service Cabang wajib memandu calon Pemegang Kartu untuk mengisi Formulir Aplikasi Share-E dan slip Transper secara lengkap;

3.1.5 Dokumen pendukung yang diperlukan untuk pembelian paket perdana adalah foto kopi identitas diri (KTP dan SIM);

3.1.6 Dalam hal calon pemegang kartu belum cakap hukum, maka harus disertakan data orang tua/ wali disertai dengan foto copy identitas diri orang tua/wali;

3.1.7 Pembelian Paket Perdana melalui Teller tidak dapat dibatalkan. Calon Pemegang Kartu membayar uang pembelian paket perdana melalui Teller dengan menggunakan Aplikasi Transfer dengan cara pengisian sebagai berikut:

a. Pada kolom penerima/beneficiary diisikan nama calon pemegang kartu.

b. Pada kolom jumlah transaksi diisikan nominal sebesar Rp. 100.000.

c. Pada kolom biaya diisikan nominal sebesar Rp. 25.000.

3.1.8 Fungsi yang digunakan untuk melakukan pembelian Share-E di Teller adalah Modul Pembelian Paket perdana Shar-E yang terdapat pada Modul Input Transaksi Teller;

3.1.9 Kartu tidak diperkenankan untuk diberikan kepada calon pembeli sebelum data pembelian diinput oleh Teller ke dalam system pembelian paket perdana;

3.1.10 Saldo awal Share-E sebesar Rp. 100.000 secara system akan dikereditkan ke rekening penabung setelah diotorisasi oleh supervisor Teller yang melakukan pengimputan data pembelian;

3.1.11 Penjualan Share-E melalui Dai Muamalat akan diatur dalam ketentuan sendiri;

3.1.12 Customer Service Cabang harus mengadministrasikan data pemegang kartu pada system kiblat dengan cara melakukan ubah data pemegang kartu pada Modul Base-Pemeliharaan;

3.1.13 Nomor Base nasabah pemegang Kartu Share-E dapat diketahui dari data pemegang rekening pada Modul Girtab-Peragaan; 
3.1.14 Cabang harus mengirimkan rekapitulasi data penjualan paket perdana kepada VBOD paling lambat pada pukul 10.00 pada hari kerja berikut dalam bentuk file text dengan nama : nocabregmmddyy.tx. contoh:101reg23082004;

3.1.15 Data penjualan paket perdana yang diperlukan oleh VBOD adalah :

Nomor Kartu Share-E

Nama Pemegang Kartu

Alamat

Total Penjualan (item ataupun jumlah dana) :

3.1.16 Pada hari kerja berikutnya Cabangharus mengirimkan seluruh dokumen penjualan (Formulir Aplikasi Share-E dan foto kopi identitas diri) kepada VBOD (Virtual Business Operation Department) bank Muamalat KPNO

3.2 Prosedur kedua untuk Pembukaan Rekening melalui Kantor Cabang Manado, sebagai berikut :

3.2.1 Calon Pemegang Kartu membeli paket perdana dengan harga sesuai ketentuan yang berlaku yaitu Rp. 125.000,00 (seratus dua puluh lima ribu) per paket;

3.2.2 Persedian paket perdana Share-E disimpan dan deregister oleh Customer Service Cabang;

3.2.3 Dokumen pendukung yang diperlukan untuk pembelian paket perdana adalah foto kopi identitas diri (KTP dan SIM);

3.2.4 Dalam hal calon pemegang kartu belum cakap hukum, maka harus disertakan data orang tua/ wali disertai dengan foto copy identitas diri orang tua/wali;

3.2.5 Pemegang kartu tidak dapat membatalkan Pembelian paket perdana melalui system SOPP POS;

3.2.6 Setoran awal nasabah sebesar Rp. 100.000 akan efektif langsung di rekening nasabah pada hari pembelian Share-E;

3.2.7 Dana hasil penjualan paket perdana ditujukan ke rekening giro Bank Muamalat di PT. Pos Indonesia dengan No. Rekening : A. 13.910 dan Atas Nama : PT. Bank Muamalat Indonesia, Tbk serta jumlah dana yang disetor adalah sebesar harga jual setelah dipotong imbal jasa;

3.2.8 Terhadap setiap kartu yang terjual PT Pos Indonesia memperoleh imbal jasa sebesar Rp. 7.000 dengan perincian :

a. Rp. 4.000 untuk imbal jasa penjualan

b. Rp. 3.000 untuk imbal jasa pemanfaatan SOPP

3.2.9 Imbal jasa tersebut akan didebet langsung dari Rekening Giro Share-E di PT. Pos Indonesia dengan nomor rekening seperti pada butir di atas;

3.2.10 Pusat rekonsiliasi Data PT. Pos Indonesia akan mengirimkan rekapitulasi data penjualan paket perdana kepada Bank Muamalat paling lambat pada pukul 10.00 hari kerja beikutnya dalam bentuk file text dengan nama : regmmddyyy.txt;

3.2.11 Data penjualan paket perdana yang diperlukan oleh Bank Muamalat adalah :

a. Nomor Referensi

b. Nomor Kartu Share-E Muamalat

c. Nama Pemegang Kartu

d. Alamat

e. Nomor telepon

f. Nama Kecil Ibu Kandung

g. Nomor KTP 

h. Jumlah Uang
i. Tanggal Input
j. Nama UPT

3.2.12 Pada hari kerja berikutnya kantor pos harus mengirimkan seluruh dokumen penjualan (formulir pembelian paket perdana dan foto kopi identitas diri) ke PO BOX Khusus MUAMALAT;

3.2.13 Setiap akhir bulan Unit Bisnis Ritel PT. Pos Indonesia membuat laporan hasil penjualan kartu Share-E ke Bank Muamalat dengan data sebagai berikut:
a. Nomor Kartu
b. Tanggal Penjualan
c. KPRK Penjual

Dalam hal ini, penulis melihat bahwa Shar-E merupakan kartu bertabungan yang memiliki keistimewaan tersendiri karena di dalam satu kartu sudah mencakup banyak fungsi seperti menabung (tanpa buku), ATM, Kartu Debit yang dapat digunakan untuk berbelanja atau membayar tagihan telepon, listrik juga untuk mengisi pulsa handphone.

4. Prosedur Penutupan Rekening shar-E

Dalam melakukan penutupan rekening Shar-E, nasabah dapat mendatangi Kantor Cabang Bank Muamalat atau Kantor Pos terdekat atau Outlet yang sudah disediakan dengan ketentuan sebagai berikut:

4.1 Penutupan rekening dengan saldo sampai dengan Rp. 10.000.000.- (sepuluh juta rupiah) dapat dilakukan dengan cara penarikan tunai langsung melalui ATM;

4.2 Jika saldo rekening berjumlah di atas Rp. 10.000,000,- (sepuluh juta rupiah) dating ke Counter SOPP Pos terdekat tem[at membeli Shar-E;

4.3 Mengisi formulir layanan Shar-E kepada petugas dan isi kemudian dikirimkan formulir tersebut ke Bank Muamalat Cabang Manado melalui SOPP Pos terdekat dengan melampirkan :

a. Formulir layanan Shar-E

b. Fotocopy identitas diri yang masih berlaku

c. Kartu ATM yang telah digunting

4.4 Melakukan pemindahbukuan saldo rekening penutupan Shar-E dengan nomor rekening 301.00042.12 melalui SALAM MUAMALAT;

4.5 Permohonan akan segera diproses lebih lanjut dan Bank Muamalat akan mengirimkan surat konfirmasi atas penutupan rekening. Keistimewaan menggunakan kartu Shar-E pada saat penutupan rekening, seluruh dana yang ada dapat ditarik seluruhnya hingga saldo nihil (Rp.0).

5. Deskripsi Fisik Shar-E

Untuk mendapat gambaran tentang kartu Shar-E sebagai bukti fisik bagi nasabah berikut dapat dilihat pada gambar di bawah ini.

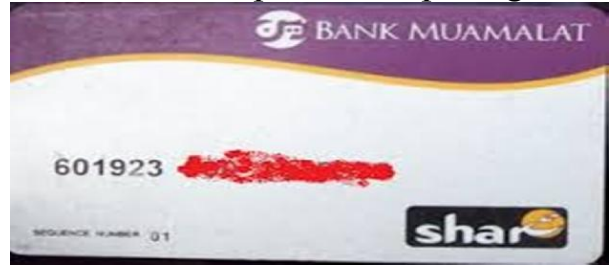

Lama

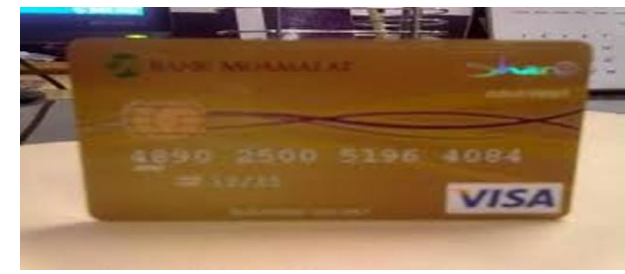

Baru 
Kartu Shar-E di atas dapat dijelaskan sebagai berikut:

5.1 Terdiri dari 16 digit nomor kartu Shar-E yang akan diminta pada saat melakukan transaksi melalui SALAMMUAMALAT.

Contoh : No kartu 6019239000000199

5.2 Ada 10 digit nomor rekening yang dapat digunakan untuk melakukan aktivitas pengisian dana rekening Shar-E baik melalui secara tunai, pemindahbukuan antar rekening di Bank Muamalat maupun transfer dari bank lain.

Contoh : Nomor Rekening 9000000199

5.3 Nomor urut kartu (sequence number) adalah nomor urut pencetakan kartu yang akan diminta pada saat melakukan transaksi mealui SALAM MUAMALAT.

6. Prosedur Penyajian Laporan Keuangan

Dalam menyajikan laporan keuangan, Bank Muamalat di dukung oleh system komputerisasi on line yangn sudah deprogram oleh kantor pusat Bank Muamalat yang berkedudukan di Jakarta. Tidak ketinggalan pula karyawan yang bekerja di bagian Akuntansi direkrut berdasarkan disiplin ilmu Akuntansi. Jadi untuk menghasilkan Data Keuangan yang nantinya diperuntukkan dalam pembuatan Laporan Keuangan yang sesuai dengan PSAK No. 59 (Akuntansi Perbankan Syariah) hanya memasukkan data ke software yang sudah ada dan sudah diprogram sesuai dengan ketentuan yang ditetapkan dalam PSAK No. 59 tersebut.

Prosedur yang diterapkan oleh Bank Muamalat Cabang Manado dalam menyajikan Laporan Keuangan adalah sebagai berikut (keadaan pada proses pembukuan produk tabungan Shar-E) :

6.1 Pengisian Data Nasabah dengan mengisi lembar yang sudah disediakan dan melengkapi dengan copyan Id Card nasabah pada bagian Customer Service. Formulir Apikasi Shar-E terdiri dari rangkap 3 (tiga) dimana lembar 1 (satu) untuk Bank Muamalat, lembar 2 (dua) untuk PT. Pos jika membuka rekening di Kantor Pos, dan lembar 3 (tiga) untuk nasabah.

6.2 Membeli shar-E dengan harga Rp. 125.000 dan berisi saldo dalam rekening Rp. 100.000 pada saat pembukaan rekening Shar-E di bagian Teller. Slip setoran mempunyai rangkap 3 (tiga) terdiri dari lembar 1 (satu) untuk Tiket Kredit, lembar 2 (dua) untuk copy Teller, dan lembar 3 (tiga) untuk nasabah.

6.3 Menambah jumlah tabungan dengan menyetor sejumlah uang tunai menggunakan slip setoran tunai di kantor cabang Bank Muamalat pada bagian Teller.

6.4 Kartu Shar-E dan kelengkapannya.

6.5 Data keuangan yang sudah diinput pada bagian teller tadi menggunakan Program Kiblat untuk Bank Muamalat diseluruh Indonesia.

6.6 Bagian Akuntansi menyelenggarakan kegiatan penjurnalan lewat computer dengan menuyang sudah ada untuk jenis biaya yang immaterial, contoh : Pengadaan Materai, Biaya Materai Nasabah, Pembelian Komputer, Biaya Perbaikan Komputer, Biaya Listrik dan air.

6.7 Data keuangan yang sudah diinput selama satu tahun akan diterima oleh Kantor Pusat Bank Muamalat yang berkedudukan di Jakarta. Data keuangan tersebut akan menjadi dasar dalam pembuatan laporan keuangan pada saat akhir tahun.

6.8 Laporan keuangan yang sudah selesai akan diperiksa pleh manajeman untuk nantinya diperiksa kembali oleh Auditor Independen yang sudah ditunjuk Bank Muamalat 
6.9 Laporan keuangan yang telah diperiksa oleh Auditor Idependen itu akan disajikan oleh Manajemen untuk nasabah atau umum yang ingin mengetahui serta memerlukan informasi yang behubungan dengan kegiatan Bank Muamalat selama satu periode berjalan.

6.10Laporan keuangan yang disajikan biasanya menampilkan laporan keuangan tahun sebelumnya sebagai pembanding dan merupakan kumpulan dari semua cabang Bank Muamalat yang ada di Indonesia.

Transaksi yang terjadi dalam kegiatan Bank Muamalat Cabang Manado semuanya diinput melalui computer dengan menggunakan program KIBLAT. Dalam program tersebut, transaksi secara otomatis dipisahkan menurut pos-pos yang nantinya pada hasil akhir setipa tutup buku tahunan akan menghasilkan laporan keuangan. Laporan keuangan Bank Muamalat Cabang Manado adalah kumpulan transaksi yang dihasilkan oleh seluruh Bank Muamalat yang ada di Indonesia.

Laporan keuangan Bank Muamalat mencerminkan tata kelola perusahaan secara Islami dan sesuai dengan praktek terbaik yang berlaku di Perbankan Nasional dan Internasional yang tidak terlepas dari Peraturan Standar Akuntansi Keuangan (PSAK) No. 59 tentang Akuntansi Perbankan Syariah. Untuk melihat lebih rinci hasil dari laporan manajemen tentang kegiatan usaha Bank Muamalat selama tahun 2013 dengan pembanding tahun 2012, penulis mengutip dari buku laporan tahunan yang diterbitkan oleh BMI dan dapat dilihat pada lampiran.

Dari hasil penelitian ini penulis mengambil analisa sebagai berikut:

1. Prosedur yang diterapkan pada Bank Muamalat dalam hal penghimpunan dana tabungan khususnya produk tabungan Shar-E yang bersifat Mudharabah sudah sesuai dengan PSAK No. 59 dimana dalam hal pengakuan dan pengukuran yang bersifat Mudharabah yakni akad kerjasama usaha antara shahibul maal (pemilik dana) dalam hal ini Bank Muamalat cabang Manado, ditentukan berdasarkan nisbah bagi hasil. Pada saat pembukaan tabungan Shar-E, jumlah bagi hasil sudah ditentukan terlebih dahulu berdasarkan nisbahnya.

2. Dalam menyajikan laporan keuangan, Shar-E yang merupakan produk tabungan sebagai penghimpun dana, disajikan dalam neraca sebagai investasi tidak terikat. Tabungan Shar-E dari Bank Muamalat ini termasuk dalam jenis mudharabah muthalaqah (investasi tidak terikat) dimana pemilik dana memberikan kebebasan kepada pengelolah dana dalam pengelolaan investasinya. Hal ini sesuai dengan ketentuan menurut PSAK No.59, dimana Mudharabah terdiri dari dua jenis yaitu mudharabah muthalaqah (investasi tidak terikat) dan Mudharabah Muqayyadah (investasi terikat). Apabila bank bertindak sebagai pengelola dana, maka dana yang diterima :

a. Dalam Mudharabah Muqayyadah disajikan dalam laporan perubahan investasi terikat sebagai investasi terikat dari nasabah

b. Dalam Mudharabah Mutlaqah disajikan dalam neraca sebagai investasi tidak terikat.

3. Dalam hal laporan keuangan Bank Muamalat, terdiri dari :
a. Neraca
b. Laporan Laba Rugi
c. Laporan Arus Kas
d. Laporan Perubahan Ekuitas 
e. Laporan Perubahan Dana Investasi Terikat

f. Laporan Sumber dan PEnggunaan Dana Zakat, Infaq, ddan Sedekah

g. Laporan Sumber dan Penggunaan Dana Qardhul Hasan

h. Catatan Atas Laporan Keuangan

Hal ini sesuai dengan aturan yang ditetapkan dalam PSAK No. 59 tentang Akuntansi Perbankan Syariah poin 152 penyajian.

\section{PENUTUP}

\section{A. Kesimpulan}

Dari hasil pengamatan dan keikutsertaan dalam kegiatan Operasional Penghimpunan Dana Tabungan Shar-E serta dihubungkan dengan judul yakni prosedur pemeriksaan atas produk penghimpunan dana tabungan sebagai evaluasi penerapan PSAK No. 59 (Akuntansi Perbankan Syariah) pada Bank Muamalat Cabang Manado, maka penulis dapat mengambil kesimpulan sebagia berikut:

1. Shar-E merupakan salah satu produk tabungan tanpa buku dari Bank Muamalat yang penghimpunan dananya dari nasabah dan memiliki keistimewaan tersendiri dengan karateristik yang melekat padanya.

2. Bagian yang terlibat dalam proses penghimpunan dana tabungan shar-E adalah CS (Customer Service) dan bagian Teller dengan komputerisasi system kiblat untuk kemudian bagian Akuntansi menyelesaikannyan agar laporan keuangan dapat dikeluarkan oleh kantor pusat setiap periode berjalan.

3. Setiap pembukaan rekening Shar-E berhubungan dengan penghimpunan dana, harus disertai prosedur pengisian data nasabah dan melampirkan Kartu Identitaas Diri (Id Card) yang masih berlaku.

4. Kartu Shar-E yang dikeluarkan oleh Bank Muamalat Tbk, Cabang Manado sudah mengalami perubahan tampilan dan kartu yang lama masih tetap bisa digunakan.

5. Setelah menelusuri system Akuntansi pada Bank Muamalat Cabang Manado yang berhubungan dengan prosedur penghimpunan Dana tabungan Shar-E menunjukkan bahwa Bank Muamalat Cabang Manado melaksanakan aturan yang terdapat dalam PSAK (Pernyataan Standar Akuntansi Keuangan) No. 59 tentang Akuntansi Perbankan Syariah secara Teoritis.

6. laporan Keuangan Bank Muamalat Cabang Manado merupakan kumpulan Data Keuangan yang diinput melalui Komputerisasi Sistem Kiblat dan dilaksanakan oleh semua Kantor Cabang yang berada di Indonesia dan disajikan secara wajar.

7. Keuntungan dan kerugian yang terjadi pada Bank Muamalat adalah menjadi tanggung jawab bersama semua nasabah Bank Muamalat. Jika Bank Muamalat mendapat keuntungan maka nasabah juga mendapat keuntungan dengan menerima Bagi Hasil sesuai dengan Nisbah yang telah disepakati saat pembukaan Rekening di Bank Muamalat. Jadi, dalam hal berbisnis dengan Bank Syariah maka setiap keuntungan dan kerugian yang dialami akan ditanggung bersama sesuai dengan akad yang telah disepakati bersama.

\section{B. Implikasi}

Dalam hal keterbatasan penelitian ini, penulis mengalami kendala dalam beberapa hal dimana sejak penelitian pertama hingga penelitian terakhir ini, terjadi beberapa kebijakan pimpinan mengenai akses untuk melakukan pengamatan secara langsung dalam pelaksanaan input data setelah melalui Costumer Service (CS). Hal ini 
disebabkan karena keterbatasan ruangan dan kenyamanan karyawan dalam melaksanakan tugasnya serta privacy dari unit akuntansi itu sendiri. Keadaan yang demikian itu sangat penulis hargai sehingga pengamatan yang penulis lakukan hanya sebatas yang diizinkan oleh pimpinan.

\section{C.Saran}

Berdasarkan observasi yang dilakukan, maka penulis dapat mengemukakan beberapa saran sebagai berikut :

1. Untuk menghimpun dana Tabungan Shar-E, sebaiknya promosi Bank Muamalat lebih ditingkatkan agar masyarakat dapat lebih mengenal Profil dari Bank Muamalat yang merupakan Bank Syariah yang dapat menjawab pilihan masyarakat muslim dimana umat muslim masih meragukan keberadaan Bank Konvensional karena alasan Riba yang bagi Umat Muslim hukum Syariatnya adalah Haram

2. Merekrut karyawan dari disiplin ilmu yang kompeten dengan perbankan Syariah agar mutu Pelayanan dan Kader manajemen dapat terus dipertahankan sebagai Bank Murni berbasis syariah.

3. Fleksibel dalam melaksanakan pekerjaan disemua bagian tanpa harus terganggu atau merasa diawasi jika ada yang ingin melakukan penelitian di Bank Muamalat.

4. Pemberian penghargaan bagi yang memiliki kinerja maksimal dan hukuman bagi yang memiliki kinerja minimal.

\section{Daftar Pustaka}

Adnan, M. Akhyar; Akuntansi Syariah : Arah, Prospek dan Tantangannya: Yogyakarta: UII Press, 2005.

Arifin, Zainul : Pengantar, M. Syafii Antonio : Dasar-Dasar Manajemen Bank Syariah: Jakarta, Alvabet, cet ke 2, Agustus 2003.

Ikatan Akuntan Indonesia; Standar Akuntansi Keuangan; Salemba Empat, per 1 Oktober 2004

Buletin Laporan Tahunan BMI tahun 2006, h. 1.

Buletin Laporan Tahunan BMI tahun 2006, h. 7.

Muhammad; Sistem dan Prosedur Operasional Bank Syariah; Yogyakarta UII Press, 2000

Mohammad Ariff, islamic banking. Asian-pasific economic literature, vol 2, No. 2 (september 1988), h. 52

Muh. Zuhri, Riba dalam Al Qur'an dan Masalah Perbankan. Jakarta: PT. Raja Grafindo persada, 1996, h. 159

Sumitro, Warkum; Asas-Asas Perbankan Islam dan Lembaga-Lembaga terkait BMI dan Takaful di Indonesia; PT.Raja Grafindo Persada,2002.

Syafi'I Antonia, Muhammad; Bank Syariah; Dari Teori ke Praktik; Gema Insani Press, 2001.

Triyuwono, Iwan; Perspektif, metodelogi dan Teori Akuntansi Syariah; PT. Raja Grafindo Persada, 2006.

Zulkifli, Sunarto; Panduan Praktis Transaksi Perbankan Syariah; Zikrul Hakim, 2003.

\section{Lampiran}

Laporan Keuangan Bank Muamalat, Tbk tahun 2013 dengan pembanding tahun 2012. 
